\title{
Recent status and population decline of the Great Bustard Otis tarda in Iran
}

\author{
AHMAD BARATI, RAHIM ABDULKARIMI and JUAN CARLOS ALONSO
}

\section{Summary}

The current distribution and recent population trends of the Great Bustard (Otis tarda) in Iran were investigated based on a literature review and unpublished data (1995-2008) followed by three years of census (2009-2011) in areas where the species is still breeding. Results suggest that Great Bustards have disappeared from a large part of their former distribution in the country, including East Azarbayjan, Hamedan and Kurdistan provinces. The surviving groups are concentrated in West Azarbayjan where numbers are rapidly declining. The present population is estimated at about $43-48$ birds in 2011, confirming a marked decline compared to the 200-300 birds estimated in the early 1990s. About $80-90 \%$ of the extant birds are concentrated in the plains of Boukan. Strict conservation measures are urgently needed to prevent the extinction of this species in Iran.

\section{Introduction}

The Great Bustard Otis tarda populations have suffered marked decline during the last two centuries and is classified as 'Vulnerable' by IUCN (BirdLife International 2012). Factors affecting Great Bustard populations are mainly loss, degradation and fragmentation of habitat caused mainly by agricultural transformation, expansion of human infrastructure and hunting (BirdLife International 2004, Palacín and Alonso 2008). The world population is currently estimated to be between 44,100 and 57,000 individuals (Alonso and Palacín 2010), distributed mainly in Spain and Russia. In Central Asia, small and fragmented populations persist (Del Hoyo et al. 1996) but the paucity of published information in Central Asian states but also in Turkey, Ukraine and notably in Iran, precludes the calculation of accurate population estimates.

Iran hosts both breeding and wintering Great Bustard; Khorasan in the east was home to wintering birds coming presumably from Central Asian breeding grounds. In the west of Iran, six provinces host a resident and a wintering population. Though the species benefits from protection since 1967 (Laws and Parliamentary Affairs Office, Department of Environment 1967), a significant decline has been perceived all over the country in recent decades, most probably due to human-induced habitat changes and to a lack of enforcement of the protective decree.

The species' status is largely unknown in most regions of Iran. A survey conducted in the early 1970 (Scott 1971b) estimated 40-100 breeding females in the north-east of the country and Razdan and Mansoori (1989) reported observation of 124 birds wintering in eastern Iran in 1976. Since 1990 (Amini 2000) and during the last two decades, Great Bustard has not been observed in eastern Iran in spite of regular monitoring. In the west of the country, Cornwallis (1983) counted 40 females breeding in 1977 and Amini (2000) estimated 6o breeding females and 200-300 wintering individuals. Recent surveys found the highest numbers of Great Bustards in West Azarbayjan and Kurdistan (Amini 2000, Barati and Amerifar 2008). 
This study reports on field surveys conducted between 2009 and 2011 in western Iran and combines new and historical knowledge on the species in the region in order to present an updated outline of its current status and trends. The most probable causes of the recent decline are discussed and possible conservation measures suggested.

\section{Methods}

Between 2009 and 2011, we conducted breeding Great Bustard surveys in western Azarbayjan: Sootav $\left(36^{\circ} 33^{\prime}-36^{\circ} 37^{\prime} \mathrm{N}, 46^{\circ} 08^{\prime}-46^{\circ} 12^{\prime} \mathrm{E}\right)$, Yengija Albelagh $\left(36^{\circ} 26^{\prime}-36^{\circ} 28^{\prime} \mathrm{N}, 46^{\circ} 13^{\prime}-46^{\circ} 17^{\prime} \mathrm{E}\right)$, Se Kanian $\left(36^{\circ} 39^{\prime}-36^{\circ} 45^{\prime} \mathrm{N}, 46^{\circ} 12^{\prime}-46^{\circ} 17^{\prime} \mathrm{E}\right)$ and Qazlian $\left(36^{\circ} 28^{\prime}-36^{\circ} 30^{\prime} \mathrm{N}, 46^{\circ} \mathrm{O} 8^{\prime}-46^{\circ} 10^{\prime} \mathrm{E}\right)$. Surveys were conducted in March-April of each year, when Great Bustards concentrate at display grounds. Additional surveys aimed at establishing seasonal changes were carried out four times per month throughout the whole study period at Sootav, West Azarbayjan.

The survey methodology used was that recommended for nationwide surveys (Alonso et al. 2000, 2003, 2005). Each census team consisted of at least two observers experienced in counting bustards and benefiting from previous knowledge of the area. Areas were travelled slowly with $4 \mathrm{x} 4$ vehicles along pre-defined $20-50 \mathrm{~km}$ routes, using mostly available tracks. Routes were defined to cover the entire area once, avoiding duplicated counts and minimising bird disturbance. Binoculars and telescopes (20 x 60) were used to search for birds during the frequent and prolonged stops at vantage points along the itinerary. Each census was carried out from dawn to dusk, with a midday pause, when birds often lie down and are more difficult to see (Alonso et al. 2003). Males, females and juveniles were distinguished whenever possible, and additional data on breeding activities, substrate used by each flock, and general habitat features of the areas were collected.

Historical information from the most reliable population estimates made in the last two decades, and using the same methods as those in our surveys, were compiled and added to the analysis. These surveys were those carried out by the Department of Environment in Hamedan (Asad Abad Hunting Prohibited Area), Kurdistan, West Azarbayjan and East Azarbayjan (Qareh Gheshlagh) (Amini 2000) as well as additional counts published in recent years (Barati and Amerifar 2008, Abdulkarimi et al. 2010a, 2010b).

\section{Results}

The results show that Great Bustards have disappeared from most areas where they were found in Iran in the last two decades (Table 1, Figure 1). Today they survive only in three areas of Boukan region, West Azarbayjan, although in two of these sites a recent declining trend is also evident (Figure 2). Data revealed sharp declines in two additional areas where information allows establishing reliable trends (Figure 2, Hamedan and East Azarbayjan). In one of these, the Qareh Gheshlag Hunting Prohibited Area, numbers decreased from 6o birds in 1990 to zero in 2008. In the Asad Abad Hunting Prohibited Area, the birds counted in 1995 had disappeared in 2004 (Figure 2). A declining trend was also recorded for all areas in Kurdistan (details in Barati and Amerifar 2008). In Qazlian, West Azarbayjan, 33 birds were seen in January 2011 and 12 birds two months later.

Surveys in Sootav show that Great Bustards are present there throughout the year (Figure 3). Highest numbers were observed in January 2009, with a maximum of 35 birds. Male numbers remained constant through the three years, whereas females decreased to 12-16 in 2010-2011. The seasonal pattern was the same through the three years, with peak numbers in winter-early spring and the lowest numbers in summer. Chicks were observed in 2009 and 2010, confirming successful breeding in this area.

In Iran, Great Bustards breed currently in remote farmland areas subject to little disturbance. The main crop in these areas is wheat Triticum aestivum, but peas Cicer arietinum, barley Hordeum vulgare, lentils Lens culinaris, alfalfa Medicago sativa, corn Zea mays and sunflower 
Table 1. Recent survey results and current estimates of the Great Bustard population in Iran.

\begin{tabular}{|c|c|c|c|c|c|}
\hline Area & Location & No. recorded (date) & Reference & Current survey (2009-2011) & Current Estimate \\
\hline Sootav & 4 km NW of Boukan & 6o (1994) & Amini (2000) & $23(7 \hat{\sigma}, 16$ $)$, April 2010 & $23-26$ \\
\hline Yengija-Albolaq & $2 \mathrm{~km} \mathrm{E}$ and SE of Boukan & $33(2008)$ & Abdulkarimi et al. (201ob) & 18 in February 2011 & 18 \\
\hline Qazlian & 4 km SW of Boukan & $13(2008)$ & Abdulkarimi et al. (2010b) & o & o \\
\hline Se Kanian & $24 \mathrm{~km}$ North of Boukan & see Fig 2 & DOE Iran & 4 P April 2010, 2 9 March 2011 & $2-4$ \\
\hline Bajvand and Azad & $20 \mathrm{~km} \mathrm{NE}$ of Mohabad & 2 (July 2007) & DOE Iran & o & o \\
\hline Hassan abad & $25 \mathrm{~km} \mathrm{NE}$ of Mohabad & & a & $\mathrm{o}$ & o \\
\hline Misalm & $26 \mathrm{~km} \mathrm{~W}$ of Boukan & & $\mathrm{b}$ & o & o \\
\hline Kani sib & $35 \mathrm{~km} \mathrm{~S}$ of Mohabad & 2 (June 2003) & DOE Iran & $\mathrm{o}$ & o \\
\hline MarhamatAbad & & $19($ Aug 74) & Fotoohi and Mansoori (1974) & o & o \\
\hline Nazloo & $15 \mathrm{~km} \mathrm{NW}$ of Urmia & 7 (March 1994) & Amini (2000) & o & o \\
\hline Qareh Gheshlagh & $15 \mathrm{~km} \mathrm{SW}$ of Bonab & 48 (1994) & Amini (2000) & o & o \\
\hline Chehar doli-Qorveh & I5 km SE of Qorveh & $\begin{array}{l}9 \text { (Aug 74) } \\
\text { I1 (1993) }\end{array}$ & $\begin{array}{l}\text { Fotoohi and Mansoori (1974) } \\
\text { Amini (2000) }\end{array}$ & o & o \\
\hline Zarrineh Obatou & $15 \mathrm{~km} \mathrm{~N}$ of Divandareh & $\begin{array}{l}38(1992) 4(2005) \\
38(1992)\end{array}$ & $\begin{array}{l}\text { Barati and Amerifar (2008) } \\
\text { Amini (2000) }\end{array}$ & o & o \\
\hline Gaveshleh & $17 \mathrm{~km} \mathrm{NE}$ of Divandareh & $8(2002) 4(2005)$ & Barati and Amerifar (2008) & o & $\mathrm{o}$ \\
\hline Yazibolaghi & $30 \mathrm{~km} \mathrm{E}$ of Saqqez & $3(2002) 2(2005)$ & Barati and Amerifar (2008) & o & o \\
\hline Saqqez Airport & near Saqqez & 8 (Aug 74) & Fotoohi and Mansoori (1974) & o & o \\
\hline Dashte-Ghaz & SW of Dehgolan & 9 (June 7I) & Scott $(1971 b)$ & o & $\mathrm{o}$ \\
\hline Asad abad & S of AsadAbad & $\begin{array}{l}14(\text { Aug } 71) \\
8(\text { Jun } 71) \\
5(\text { Aug } 74) \\
\text { 10 (1994) }\end{array}$ & $\begin{array}{l}\text { Scott (1971a) } \\
\text { Scott (1971b) } \\
\text { Fotoohi and Mansoori (1974) } \\
\text { Amini (2000) }\end{array}$ & o & $\mathrm{o}$ \\
\hline Telesm & near Kerand Kermanshah & $\begin{array}{l}7(\text { Aug } 71) \\
2(\text { Aug } 74)\end{array}$ & $\begin{array}{l}\text { Scott (1971a) } \\
\text { Fotoohi and Mansoori (1974) }\end{array}$ & o & o \\
\hline Total & & & & 45 & $43-48$ \\
\hline
\end{tabular}

a) No confirmed record for at least 20 years, b) No confirmed record for at least to years. 


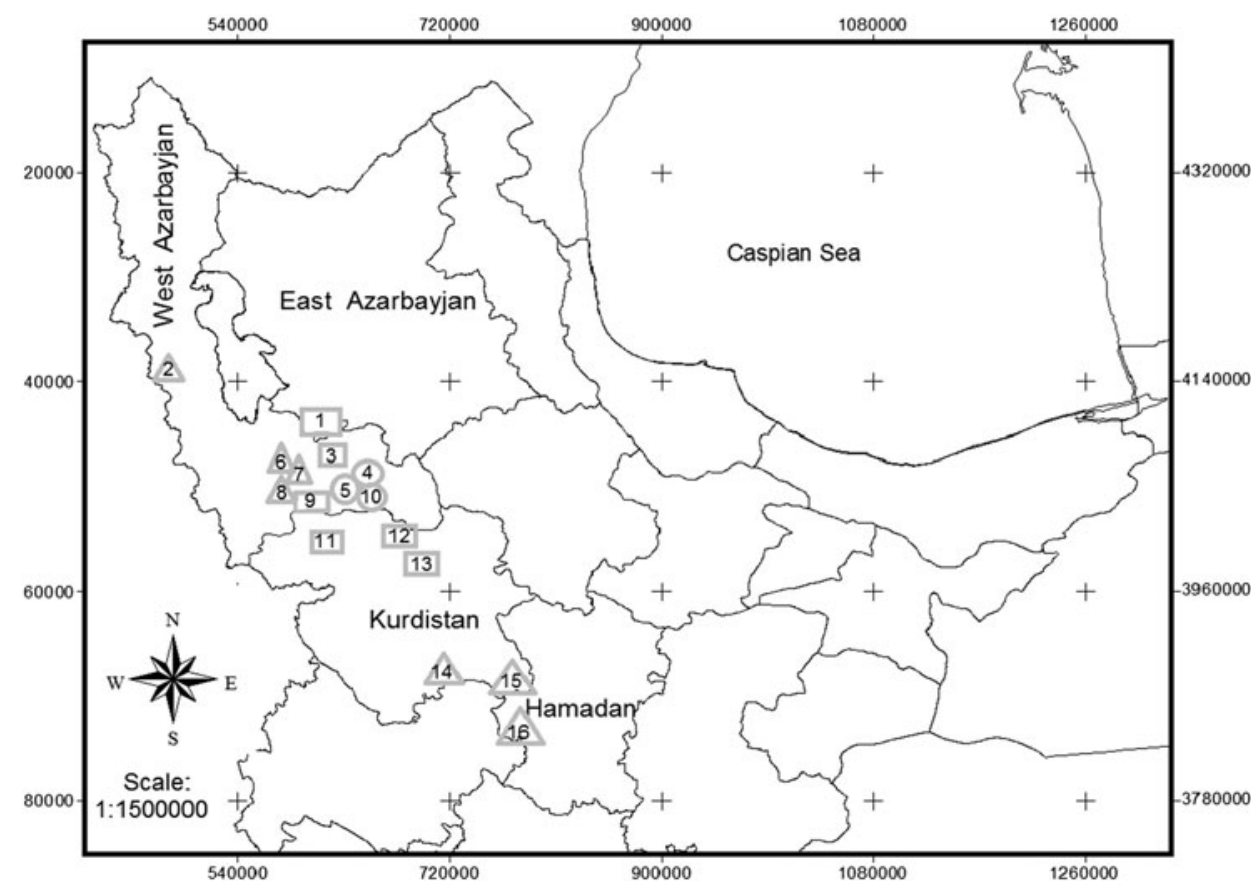

Figure 1. Map showing current and previous areas occupied by Great Bustards in northwest Iran (1: Qareh Gheshlagh , 2: Nazloo, 3: Azad and Bajvand, 4: Se Kanian, 5: Sootav, 6: HassanAbad, 7: Misalm, 8:Kani sib, 9: Qazlian,10: Yengija-Albolaq, 11: Yazibolaghi, 12: Zarrineh Obatou, 13: Gaveshleh, 14: Dashte-Ghaz, 15:Cahehar-duli Qorveh, 16: Asad Abad) Triangles = Areas where Great Bustards are assumed to be extinct (not observed for at least 1o years); rectangles $=$ Areas with unknown status (not observed for more than 5 years); circles = areas with extant populations (presence confirmed during the present study).

Helianthus annuus are grown as well. Human population density and the impact of farming activities are generally low in these areas.

\section{Discussion}

Our study confirmed that Great Bustards have disappeared from much of their former distribution range in Iran. For example, in Kurdistan there are no records since 2005 and in Hamedan since 2003 . The main areas formerly used in these provinces are now almost entirely cultivated. In Qareh Gheshlagh, East Azarbayjan, the last record is from 2007.

The apparent reason for the population decline is agricultural intensification in recent decades. Many areas formerly farmed in a traditional way, and thus suitable for the species, are now under intensive cultivation and often irrigated. Consequently, human population density and presence in the fields have increased in most areas, such as in the plains of Asad Abad where habitat degradation and the disappearance of fallow land have probably been the main causes of extinction (AB pers. obs.). A similar scenario is found in Kurdistan, where the last observations of Great Bustards date back to 2005. Here changes in farming systems have been accompanied by an increase in livestock and shepherding activities, and the construction of new roads and power lines (Barati and Amerifar 2008).

The only region where conditions remain suitable for the species in Iran is West Azarbayjan. Great Bustards are found there in Sootav, Yengija-Albolaq and Se Kanian, all around Boukan city. 


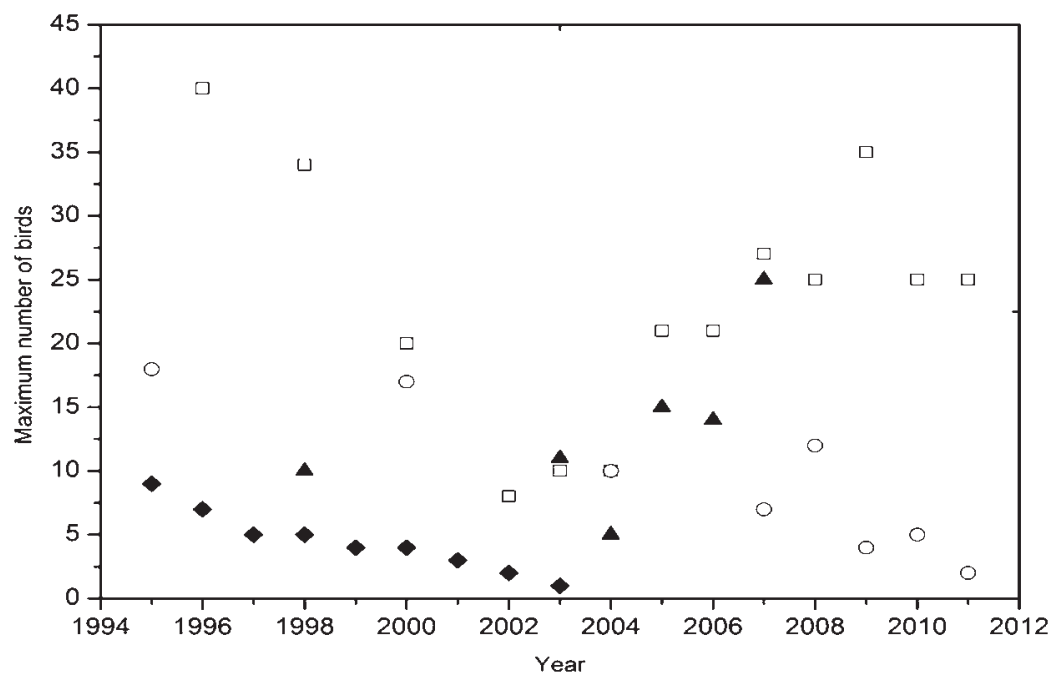

Figure 2. Maximum numbers of Great Bustards counted at four areas of western Azarbayjan province in the last two decades ( $\square$ Sootav; $\circ$ Se Kanian; $\Delta$ Qareh Gheshlagh $\downarrow$ Asad Abad).

The main crops include wheat, barley, chickpeas, sunflower and alfalfa, and the area has been subjected to a lower degree of agricultural intensification and presents a lower human population density compared to other regions in Iran (Barati and Amerifar 2008). The total number of Great Bustards in these areas is currently estimated at $43-48$ individuals. Sootav is the most important site and represents today the main stronghold for the species in the country. Nesting was also confirmed here in May and June 2009 (Abdulkarimi et al. 2010a).

In Sootav, bird counts varied throughout the year, peaking in winter and early spring and showing minimum numbers in summer. These seasonal changes probably reflect in part an easier counting of the birds when they concentrate at lek sites to mate, and the greater higher difficulty in finding them afterwards, when females have dispersed to nest and males stop displaying and are less

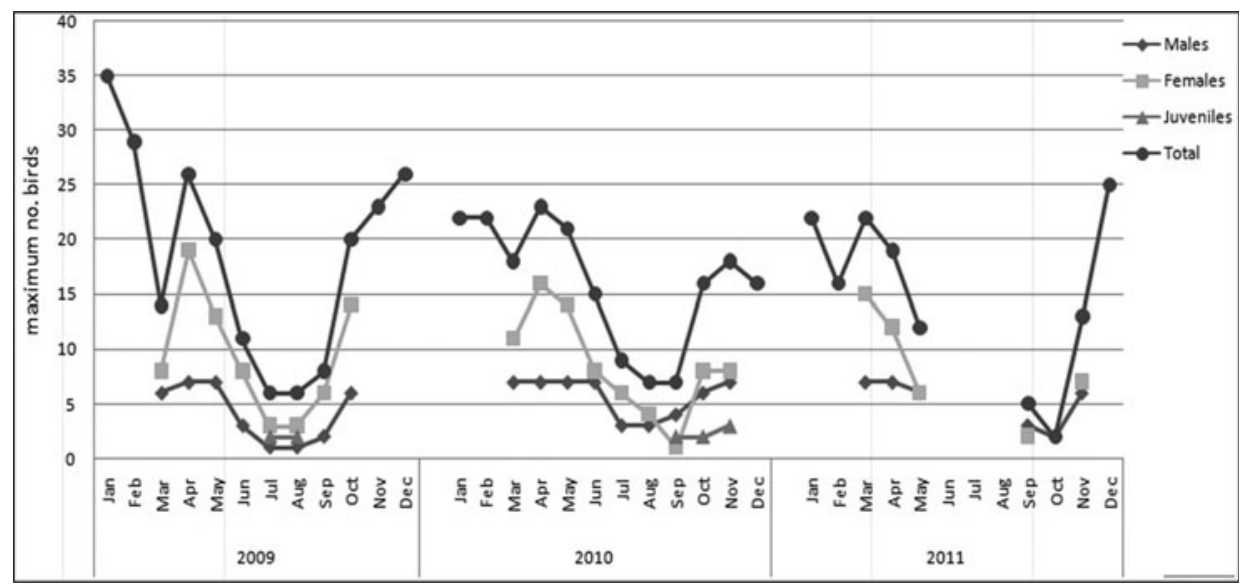

Figure 3. Monthly variations in maximum numbers of Great Bustards. Data accumulated for Sootav, Boukan, West Azarbayjan province for years 2009-2011. 
visible (Alonso et al. 1995, 2003). However, in the case of males, we cannot discard the possibility of a partial summer migration similar to that occurring in the Iberian Peninsula, where a variable number of males abandons the lek areas after mating to spend the summer at more convenient, cooler and undisturbed sites (Alonso et al. 2009). The lack of marked birds prevents us from knowing exactly what the birds do during summer, but probably the smaller numbers of birds counted in summer at the lek areas is due to both nesting dispersal of females and summer migration of males.

As for Qazlian plains, the whole area was cultivated with dry cereals in the past, but during the last decade an increasing number of fields are being irrigated. The consequent increase in human presence has probably caused Great Bustards to abandon this area during the breeding season (Abdulkarimi et al. 2010b). Recent observations suggest that a number of individuals still use the area in winter, probably benefiting from the alfalfa fields which are here abundant (Abdulkarimi et al. 2010b). As for Se Kanian, the area seems to be less important for breeding than other areas in the region.

In Kurdistan, Great Bustards have been reported breeding in the early 1990s (Amini 2000, Barati and Amerifar 2008), with scattered observations of a few birds in 2002-2005 (present study). However, as in other regions of Iran, agricultural intensification and human-induced habitat degradation are probably the causes of the local extinction of the last breeding groups in recent years.

\section{Conservation measures}

Based on our results, strict conservation measures should be urgently undertaken to prevent the extinction of Great Bustards in Iran. The most important of these measures should definitely be to stop the current agricultural intensification process in the three areas near Boukan where the species still survives. In other areas of their distribution range, it has been clearly established that Great Bustards need large extents of dry cereal farmland and extensive cultivation to breed successfully, and that intensive farming regimes, and particularly irrigated crops have a negative effect on their breeding performance (Alonso and Alonso 1990, Lane et al. 2001, Alonso et al. 2003, Pinto et al. 2005). The same habitat preferences and detrimental effects of intensive farming practices can be inferred from our comparison between Great Bustard survey results and progress of agricultural intensification in Iran (Barati and Amerifar 2008, Abdulkarimi et al. 201ob, and unpubl. data on habitat selection). The fact that in Iran bustards frequently occur in privately owned land may represent an additional difficulty in developing management programmes. Therefore, Amini's (2000) suggestion that the Department of Environment should purchase some of these private properties to establish bustard reserves could be considered. An alternative would be to establish agri-environmental schemes under official supervision and funding, similar to those that have helped reverse negative trends, or even saving some of the most endangered populations of this species from extinction in other countries (Raab et al. 2010, Garrido and De las Heras 2012, Raab 2013). If appropriate measures are implemented in the Sootav plains, where the largest extant group occurs in Iran, bird numbers could increase there and eventually act as a source of individuals for smaller groups, as has apparently occurred in populations elsewhere (Pinto et al. 2005, Raab 2013).

If funding allows it, it would be advisable not to restrict management plans just to the areas where Great Bustards are present today, but also to those where it has gone extinct in recent years. If appropriate habitat is restored in these sites, they could be potentially re-colonized and guarantee the long-term survival of the whole metapopulation.

Finally, in Iran there is no clear evidence of a migratory pattern of Great Bustards inside and outside the country, and the population is probably too isolated to receive dispersing individuals from other countries (e.g. Turkey). Studies involving tracking marked birds to confirm whether these migratory trends exist or not would also be of great help.

All the above mentioned measures will provide the baseline for an effective management plan that may help save this highly endangered species from extinction in Iran. However, they would 
be meaningless without a campaign to raise public awareness on the importance of Great Bustards, and a permanent monitoring programme based on a yearly survey of the bird numbers in spring, and particularly the breeding success of the extant populations, that can be used to evaluate the success of the measures applied. Such monitoring programmes have been fundamental to the conservation of the most severely threatened populations of this species (Langgemach 2011, Garrido and De las Heras 2012, Raab 2013).

\section{Acknowledgements}

A part of this work was supported by DoE Boukan office. We wish to thank Mr. Abbas Nejad, Director General of DoE, West Azarbayjan, Mr. M. Ahmadi, head of DOE Boukan Office, and all farmers from the study areas for their collaboration. The comments from the editor and associate editor helped improving an earlier version of the manuscript.

\section{References}

Abdulkarimi, R., Abbasnejad, H., Ahmadi, M. and Barati, A. (2010a) A note on breeding of the Great Bustard Otis tarda in Sootave Plain, Boukan, northwestern Iran. Podoces 5: 104-106.

Abdulkarimi, R., Daneshyar, M. and Barati, A. (2010b) Current status of the Great Bustard Otis tarda in Boukan, West Azarbayjan, Iran. Podoces, 5: 63-68

Alonso, J. C. and Alonso, J. A., eds. (1990) Parámetros demográficos, selección de hábitat y distribución de la Avutarda en tres regiones españolas. Madrid, Spain: ICONA.

Alonso, J. C. and Palacín, C. (2010) The world status and population trends of the Great Bustard: 2010 update. Chinese Birds I: 141-147.

Alonso, J. C., Alonso, J. A., Martín, E. and Morales, M. B. (1995) Range and patterns of Great Bustard movements at Villafáfila, NW Spain. Ardeola 42: 73-81.

Alonso, J. C., Lane, S. J., Dawson, R. and Idaghdour, Y. (2000) Great Bustards Otis tarda in Morocco: status in spring 1999 and evidence of a decline in recent decades. Oryx 34: 141-146.

Alonso, J. C., Palacin, C. and Martin, C. A. (2003) Status and recent trends of the Great Bustard (Otis tarda) population in the Iberian Peninsula. Biol. Conserv. 110: 185-195.

Alonso, J. C., Palacin, C. and Martin, C. A. (2005) La Avutarda Común en la Península Ibérica: población actual y método de censo. Madrid: SEO/BirdLife.
Alonso, J. C., Palacín, C., Alonso, J. A. and Martín, C. A. (2009) Post-breeding migration in male Great Bustards: low tolerance of the heaviest Palaearctic bird to summer heat. Behav. Ecol. Sociobiol. 63: 1705-1715. Amini, H. (2000) The status of Great Bustard Otis tarda in Iran. Sandgrouse 22: 25-31.

Barati, A. and Amerifar, A. A. (2008) On the status of the Great Bustard Otis tarda in Kurdistan Province, Iran. Zool. Middle East 43: 41-48.

BirdLife International. (2004) Birds in Europe: Population estimates, trends and conservation status. Cambridge, UK: BirdLife International. (BirdLife Conservation Series No. 12).

BirdLife International (2012) Otis tarda. In: IUCN 2012. IUCN Red List of Threatened Species. Version 2012.1. <www.iucnredlist. org $>$. Downloaded on 04 September 2012.

Cornwallis, L. (1983) A review of the bustard situation in Iran. In P. D. Goriup and H. Vardhan, eds. Bustards in decline. Jaipur, India: Tourism and Wildlife Society of India.

Del Hoyo, J., Elliott, A and Sargatal, J., eds. (1996) Handbook of the birds of the world. Vol. 3. Hoatzin to auks. Barcelona, Spain, Lynx Edicions.

Fotoohi, H. and Mansoori, J. (1974) Great Bustard surveys in Iran. Department of Environment of Iran.

Garrido, J. R. and De las Heras, M. (2012) Programa de ermergencias, control epidemiológico y seguimiento de fauna silvestre de Andalucía. Seguimiento de aves terrestres de Andalucía. Reproducción 2012. Junta de Andalucía. Unpubl. Report. 
Lane, S., Alonso, J. C. and Martín, C. A. (2001) Habitat preferences of Great Bustard Otis tarda flocks in the arable steppes of central Spain: are potentially suitable areas unoc-cupied? J. Appl. Ecol. 38: 193-203.

Langgemach, T. (2011) Zum Stand des Scghutzprojektes für die Grosstrappe in Deutschland. Vogelwarte 49: 352-353.

Palacín, C. and Alonso, J. C. (2008) An updated estimate of the world status and population trends of the Great Bustard Otis tarda. Ardeola, 55: 13-25.

Pinto, M., Rocha, P., and Moreira, F. (2005). Long-term trends in Great Bustard (Otis tarda) populations in Portugal suggest concentration in single high quality area. Biol. Conserv. 124: 415-423.

Raab, R. (2013) Foundations for the conservation of the West-Pannonian Great
Bustard (Otis tarda) population. Ph.D. thesis, University of Vienna.

Raab, R., Kollar, H. P., Winkler, H., Faragó, S., Spakovszky, P., Chavko, J., Maderič, B., Škorpíková, V., Patak, E., Wurm, H., Julius, E., Raab, S. and Schütz, C. (2010) Die Bestandsentwicklung der westpannonischen Population der Großtrappe, Otis tarda Linnaeus 1758, von 1900 bis zum Winter 2008/2009. Egretta 51: 74-99.

Razdan, T. and Mansoori, J. (1989) A review of the bustard situation in the Islamic Republic of Iran. Bustard Studies 4: 135-145.

Scott, D. A. (1971a) Preliminary survey of status and distribution of the Great Bustard Otis tarda in western Iran. Iran Game and Fish Department. Unpubl. Report.

Scott, D. A. (1971b) Aerial Survey of Great Bustard habitats. Department of Environment of Iran.

\section{AHMAD BARATI* \\ Avian Behavioural Ecology Laboratory, Zoology, University of New England, Armidale, Australia. \\ Department of Environment, Malayer University, Iran.}

\section{RAHIM ABDULKARIMI}

Department of the Environment of Iran, Boukan Office, Boukan, Iran.

\section{JUAN CARLOS ALONSO}

Departamento de Ecología Evolutiva, Museo Nacional de Ciencias Naturales (CSIC), José Gutiérrez Abascal 2, Madrid, E-280o6 Spain.

*Author for correspondence; email:abarati@myune.edu.au

Received 4 September 2013; revision accepted 7 October 2014; Published online 18 February 2015 